\title{
KETERAMPILAN PSIKOLOGIS MODEL BIMBINGAN KONSELING PROAKTIF UNTUK GURU SEKOLAH DASAR
}

\author{
Nuryati Atamimi \\ Fakultas Psikologi Universitas Gadjah Mada \\ email: atamiminuryati@gmail.com
}

\begin{abstract}
Abstrak: Model bimbingan dan konseling proaktif dirancang sebagai upaya untuk melatih dan membekali para guru dengan kemampuan psikologi yang diperlukan. Penelitian ini dilakukan di MIN Tempel Sleman Yogyakarta. Terdapat delapan guru yang termasuk dalam kelompok perlakuan dan delapan wali murid sebagai kelompok kontrol. Subjek penelitian dipilih menggunakan metode purposive sampling. Penelitian ini menggunakan rancangan quasi experiment dengan pre-test dan post-test. Model BK-Proaktif diberikan melalui pelatihan keterampilan psikologi oleh tim 6 jam setiap hari selama 2 hari. Peneliti mengamati efektivitas perlakuan selama 4 bulan sejak perlakuan diberikan dengan mengamati dan menginterviu subjek penelitian dan orang-orang yang telah mengenal subjek lebih dari satu tahun. Post-test diberikan saat observasi terakhir. Analisis data diolah menggunakan analisis kuantitatif, statistik Mann Whitney dan analisis kualitatif yang menggunakan observasi dan wawancara. Hasil penelitian menemukan bahwa tidak ada perbedaan persepsi diri, self-esteem, dan motivasi kerja antara kelompok perlakuan dan kelompok kontrol pada Pre-post 2.
\end{abstract}

\section{Kata Kunci: bimbingan konseling, persepsi diri, harga diri, motivasi kerja}

\section{PSYCHOLOGICAL SKILLS OF PROACTIVE GUIDANCE AND COUNSELING MODEL FOR ELEMENTARY SCHOOL TEACHERS}

\begin{abstract}
The model of proactive guidance and counseling was compiled as an effort to train and equip school teachers with psychological skills needed. This study was carried out at MIN Tempel Sleman Yogyakarta. There were 8 teachers included in the experimental group, and 8 classroom teachers were included in the control group. The research subjects were selected using the purposive sampling method. The research used a quasi experiment study with a pre-test and a post-test. The proactive guidance and counseling model was given in the form of psychological skill training, by a trained team. The training took place for 2 days, 6 hours/day. The researcher monitored the effectiveness of the treatment for 4 months after training by observation and interviews with research subjects and other people who know the subjects for more than 1 year. The post-test was given at the end of the monitoring. The data were analyzed using the quantitative analysis, Mann Whitney statistics and qualitative analysis. The findings showed that there was no significant difference in self-esteem and work motivation between Post 1-Pretest and Post 2-Pretest, Post 2-Pretest and Post 2-Post1 variables. There was no significant difference in self-esteem variables between Post 1-Pretest and Post 2-Pretest, Post 1 - Post 2 and Pretest - Post. Finally, the research confirmed that there was no difference in self-perception, self-esteem, and work motivation between the experimental group and the control group on Pretest-Post 2.
\end{abstract}

Keywords: guidance counseling, self perception, self-esteem, work motivation

\section{PENDAHULUAN}

Penelitian ini merupakan pengembangan dari hasil penelitian yang telah dilakukan sebe- lumnya untuk menguji Model Bimbingan Konseling (BK) Proaktif terhadap keterampilan psikologis guru BK tingkat SMP di Kabupaten Bang- 
ka. Hasil penelitian menemukan ada peningkatan secara signifikan, yaitu persepsi guru BK tentang diri pribadi dan profesi sebagai konselor sekolah, persepsi terhadap harga diri, kepercayaan diri, kepuasan kerja dan motivasi kerja setelah mereka diberikan pelatihan keterampilan psikologis Model BK Proaktif selama 30 jam efektif.

Selanjutnya, hasil penelitian ini diterapkan terhadap guru SD di Yogyakarta dengan mempertimbangkan Keputusan Menteri Negara Pendayagunaan Aparatur Negara Nomor 84 Tahun 1993 tentang Jabatan Fungsional Guru dan Angka Kreditnya yang menyatakan bahwa setiap siswa berhak memperoleh pelayanan dari guru BK dan disebut sebagai siswa asuh bagi guru. Artinya, setiap sekolah di Indonesia mulai jenjang SD hingga SMU masih membutuhkan peran BK untuk memenuhi aturan pemerintah dalam usaha membantu siswa menjalankan tugas perkembangan mereka.

Kurikulum tahun 2004 menunjukkan bahwa keberadaan layanan BK yang ditangani oleh guru BK dalam sistem pendidikan secara formal dimulai ditingkat SLTP. Pada umumnya di Indonesia untuk tingkat SD pemberian layanan BK masih melekat pada guru kelas yang memiliki posisi penting dalam pemberian layanan BK sebab guru kelas lebih mudah memantau setiap perkembangan yang terjadi pada peserta didik. Menjadi guru BK di tingkat SD tentu akan berbeda metode dan cara pendekatan terhadap peserta didik. Siswa SD masih termasuk usia anak bukan remaja sehingga perlu pendekatan khusus dalam berinteraksi dengan siswa. Perkembangan fisik dan psikologis (kognisi, afeksi, etika, moral) paling peka di usia SD. Intervensi jangka panjang bidang pendidikan sebagai usaha untuk mengantisipasi berbagai kenakalan di usia remaja yang semakin bervariasi perlu didukung dengan keberadaan guru kelas yang terampil dan profesional agar siswa SD dapat berkembang optimal sesuai dengan usia perkembangan dan potensi dasarnya. Penelitian ini ingin membuktikan bahwa model BK Proaktif efektif memberikan solusi untuk guru kelas SD dalam meningkatkan keterampilan psikologisnya sehingga akan berimbas positif bagi peserta didik dalam menyelesaikan tugas perkembangannya di usia SD.
Dalam memahami dan menganalisis perilaku guru dalam latar belakang masalah pada penelitian ini, dasar teori yang diacu adalah teori dari kelompok psikoanalisa Adlerian. Konsentrasi Adlerian melekat pada minat sosial (social interest) dari individu, menekankan pada pengembangan sosial, kerja sama, dan pendidikan. Adler pada awalnya menggunakan kelompok untuk kegiatan konseling dan psikoterapi. Di antara prinsip utama teori Adler adalah kepeduliannya pada minat sosial. Esensi normalitas dalam pandangan Adler adalah memiliki perasaan yang peduli terhadap orang lain dan dapat dikembangkan dalam konteks dengan aktivitas kelompok (Adler, 1956).

Model adalah sebuah abstraksi dan lebih bermanfaat untuk tujuan tertentu, lebih rinci, menggambarkankeadaan yang sesungguhnya secara lebih utuh. Model diperlukan untuk menggambarkan realitas dan mampu untuk menyederhana annya melalui cara yang sebaik-baiknya sesuai dengan keperluan pengguna (Huntington, 2001). Joyce dan Weil (1980) mengemukakan bahwa pada hakikatnya model adalah rencana atau pola yang dapat digunakan dalam kegiatan tertentu. Model apapun yang dirancang akan digunakan untuk membantu dalam memahami sesuatu. Model BK Proaktif dalam penelitian ini merupakan model BK untuk mengembangkan keterampilan guru BK, menggali dan menggunakan sumber-sumber potensial yang ada di lingkungan sekitar.

Model BK Proaktif dalam penelitian ini menggunakan pelatihan untuk meningkatkan keterampilan psikologis guru. Pelaksanaan secara kelompok menurut teori Adler dapat dilakukan melalui empat tahapan, yaitu: (1) membangun dan memelihara hubungan terapiutik yang tepat; (2) mengeksplorasi dinamika yang terjadi dalam diri anggota kelompok; (3) mengomunikasikan suatu pemahaman diri kepada setiap anggota kelompok; dan (4) menemukan serta mengembangkan berbagai alternatif dan pilihan baru untuk pengembangan diri anggota kelompok.

Corey (1990) mengemukakan bahwa anggota kelompok akan memperoleh pengalaman yang lebih berorientasi sosial, terintegrasi se- 
cara pribadi, mampu memperbaiki beliefs yang salah sehingga dapat menentukan arah tujuan hidupnya. Keuntungan dari teori Adler untuk aktivitas kelompok adalah penekanan pada unsur pendidikan sehingga anggota kelompok akan menikmati pengalaman dan perasaan mereka secara realistis ketika menangani masalah. Berdasarkan pada logika, akal sehat, dan menggunakan cara kognitif dan eklektik agar anggota kelompok tidak merasa terhambat oleh prosedur yang digunakan sehingga mendorong partisipasi anggota untuk berperilaku demokratis dalam meningkatkan keterbukaan dan dialog. Aspek perilaku dan afeksi diperhatikan serta tidak terikat dengan metode dan prosedur yang kaku.

Teori Adler tentang inferiority complex guru karena keterbatasan profesional dan perlakuan yang mereka terima akan manifes dalam bentuk tingkah laku superior. Teori ini dapat menjelaskan dinamika perilaku guru sehingga guru cenderung dipersepsi negatif. Guru yang inferior akan mempersepsikan dirinya negatif, sehingga harga diri, kepercayaan diri, kepuasan kerja, dan motivasi kerja cenderung rendah

Pelaksanaan Model BK Proaktif menggunakan pelatihan untuk meningkatkan keterampilan psikologis guru kelas SD. Pelaksanaan pelatihan secara kelompok mengacu kepada minat sosial yang dapat dilakukan melalui empat tahapan, yaitu sebagai berikut. Pertama, membangun dan memelihara hubungan terapiutik yang tepat karena minat sosial yang tidak berkembang, menjadi faktor yang melatarbelakangi semua jenis gangguan penyesuaian. Kedua, mengeksplorasi berbagai dinamika yang terjadi dalam diri anggota kelompok karena ingatan orang mengenai masa kecilnya sering dapat mengungkap asal mula gaya hidup yang menjadi sumber berbagai masalah yang mengganggu. Ketiga, mengomunikasikan sesuatu tentang pemahaman diri kepada setiap anggota kelompok bahwa kehidupan manusia bukan penerima pengalaman secara pasif, tetapi manusia adalah aktor dan inisiator bagitingkahlakunya. Keempat, menemukan serta mengembangkan berbagai alternatif dan pilihan baru untuk pengembangan diri anggota kelompok. Setiap anggota kelompok akan memperoleh pengalaman yang lebih berorientasi so- sial, terintegrasi secara pribadi dan mampu memperbaiki beliefs yang salah sehingga dapat menentukan tujuan hidupnya (Alwisol, 2007).

Pelatihan yang menggabungkan aspek kognitif, afektif, psikomotorik pada masa sekarang menjadi sarana pendidikan yang penting untuk meningkatkan aktualisasi diri karena pada pelatihan tersebut terdapat unsur diskusi, percobaan, pengetahuan, keingintahuan, kegembiraan yang berkontribusi pada peningkatan kemampuan, produktivitas, dan kesiapan menjadi guru sekaligus pembimbing dan pemimpin efektif (Silberman, 1998). Pendekatan pelatihan yang digunakan adalah memberikan pengalaman langsung kepada para peserta pelatihan (experiential learning). Metode yang dipakai ialah dengan cara memberikan simulasi melalui ceramah, brainstorming, role play dan game atau sebuah permainan yang secara langsung dampaknya dapat dirasakan dan direfleksikan oleh peserta.

Keterampilan psikologis memuat serangkaian kemampuan dan pengetahuan yang dimiliki individu. Keterampilan ini dapat menunjang individu untuk menyadari kemampuan diri sepenuhnya, tahan terhadap tekanan yang muncul dalam kehidupan, produktif, berperan aktif dalamkomunitas, mampu mengatasi masalah yang sedang dihadapi, dan dapat menyesuaikan diri secara tepat (Hadjam, 2005). Oleh karena itu, dalam lingkup pengembangan dan pelatihan apa pun bentuknya, keterampilan hubungan antarmanusia (people skill) menjadi sangat penting untuk semua bidang pekerjaan.

Dalam setiap pekerjaan orang harus antusias dan memiliki motivasi tinggi, mampu bekerja sama untuk memperoleh hasil yang terbaik (Rae, 2005). Kebutuhan masyarakat untuk terus-menerus belajar dalam berbagai bidang telah dibahas dalam kesepakatan global oleh Forum Dunia untuk Pendidikan (The World Forum for Education) di Dakar pada tahun 2000 yang telah menetapkan betapa pentingnya keterampilan psikologis. Tertulis dalam kesepakatan tersebut bahwa "kepastian terpenuhinya kebutuhan belajar untuk semua usia dapat tercapai dengan terlaksananya program yang berbasis keterampilan psikologis" (UNICEF, 2000). 
Persepsi yang timbul dalam diri individu dapat berubah. Perubahan persepsi dapat terjadi dalam waktu yang cepat, bahkan seketika. Namun, tidak demikian halnya dengan paradigma sebagai hasil persepsi umum orang banyak, meskipun dapat berubah akan memerlukan waktu lebih lama (Covey, 1997). Perubahan persepsi maupun paradigma terjadi karena adanya perubahan pada berbagai faktor yang berpengaruh dalam pembentukan persepsi. Walgito (2002) mengungkapkan ada dua faktor yang mempengaruhi perubahan persepsi. Pengetahuan dan konsep yang telah dimiliki individu sebelumnya merupakan salah satu faktor internal yang berpengaruh dalam mengubah persepsi individu. Pengetahuan yang dimiliki individu senantiasa berubah seiring dengan bertambahnya pengalaman individu sehingga hal ini akan mengakibatkan perubahan persepsi individu. Faktor eksternal yang memengaruhi perubahan persepsi antara lain adalah perubahan yang terjadi pada stimulus atau objek persepsi. Selain itu, perubahan faktor lingkungan juga turut berperan dalam perubahan persepsi.

Kemajuan teknologi sangat berpengaruh terhadap persepsi individu. Penggunaan online untuk kebutuhan konseling bagi konselor sekolah sangat tergantung dari kondisi yang mendukung. Konseling online dapat diberikan jika siswa dapat menerimanya. Sebagian besar responden masih merasa kurang percaya dengan implikasi legalitas dan etika terhadap konseling online. (Glasheen, dkk., 2013). Penelitiandi Turki tentang persepsi dan opini konselor terhadap program bimbingan dan konseling di sekolah menengah kejuruan juga memiliki sisi positip dan negatip, ada yang mendukung dan ada pula yang tidak. Hal ini membhuktikan bahwa persepsi setiap orang berbeda terhadap obyek yang dipersepsikan (Torunoglu \& Genctanirim, 2015).

Harga diri merupakan bagian penting dari konsep diri individu dalam membentuk tingkah laku efektif. Dengan demikian, peran harga diri menjadi sangat penting. Individu yang memiliki harga diri tinggi, memiliki karakteristik sebagai individu yang aktif, ekspresif cenderung sukses dalam bidang akademis dan kehidupan sosialnya. Hasil penelitian menunjukkan bahwa harga diri dapat ditingkatkan melalui salah satu atau kombinasi dari empat aspek, yaitu: fisik, sosial, intelektual, dan spiritual (Aldrige \& Clayton, 1990). Penelitian Temple dan Robson (1991) menemukan bahwa latihan asertif dapat meningkatkan harga diri.

Bimbingan dan konseling yang berkembang saat ini adalah bimbingan dan konseling perkembangan yang memunyai visi edukatif, pengembangan diri, dan lingkungan tepat guna. Visi edukatif menekankan pada kepedulian BK terhadap pencegahan, korektif, dan terapeutik. Visi pengembangan menekankan pada strategi perkembangan individu yang optimal sehingga berupaya untuk memperoleh kemudahan melalui pemberdayaan lingkungan. Visi lingkungan tepat guna mentargetkan objek layanan BK dengan dimensi yang lebih beragam, tidak hanya untuk individu yang bermasalah saja, tetapi mencakup target intervensi, setting, metode, dan layanan operasional BK (Nurihsan \& Sudianto, 2005).

Motivasi kerja merupakan pendorong di dalam diri individu yang berpengaruh atas tingkat, arah, dan gigihnya upaya seseorang dalam pekerjaannya yang menimbulkan semangat atau dorongan kerja, dan berpengaruh terhadap sikap dan perilaku individu dalam kerja (Schemerhorn, dkk., 2002). Dengan demikian, dapat disimpulkan bahwa motivasi kerja adalah segala sesuatu yang menimbulkan gairah, hasrat, keinginan, dan energi dari dalam diri, yang dapat mempengaruhi, dan mengarahkan, serta memelihara perilaku untuk mencapai tujuan yang diinginkan sesuai dengan ruang lingkup kerjanya (Sanmustari, 1988). Penelitian ini bertujuan untuk menguji apakah pelatihan keterampilan psikologis model BKProaktif mampu meningkatkan persepsi diri, harga diri, dan motivasi kerja menjadi lebih baik.

Model BK Proaktif yang ditampilkan melalui pelatihan keterampilan psikologis, berusaha memfasilitasi pengembangan potensi diri guru BK, memberi kesempatan untuk menjadi diri yang positif, aktif, kreatif, konstruktif, maju, berkembang, mau berproses sehingga mampu mengaktualisasikan diri seutuhnya. Teori humanistik memiliki karakteristik sebagai berikut. 
Pertama, manusia dipandang sebagai makhluk yang dilahirkan dengan membawa potensi dasar yang baik, positif, konstruktif, rasional, realistis memunyai kemauan untuk maju, dan berkembang secara sempurna.

Kedua, bebas, tidak terikat pada belenggu masa lalu, memiliki kapasitas untuk menilai diri, berorientasi ke masa depan untuk menjadi diri seutuhnya (self fulfillment), mampu membawa dirinya untuk bertingkah laku sehat dan seimbang. Jika mengalami hambatan dan kegagalan, maka akan menimbulkan masalah dan terjadi penyimpangan perilaku.

Ketiga, manusia proaktif-reaktif untuk mencapai positive striving, dan bertanggung jawab terhadap apa yang dilakukannya.

Keempat, perilaku manusia tidak hanya dipandang sebagai sesuatu yang mekanistik, tetapi harus dipandang sebagai kualitas manusia yang kreatif, berusaha untuk dapat mengaktualisasikan diri, memeroleh sesuatu dan mempertahankannya.

Kelima, menekankan pada emotional process bukan pada intelectual process, bukan pada apa yang dipikirkan atau dilakukan, tetapi bagaimana individu mengalaminya dan merasakan kehidupannya. Keenam, individu yang mengalami kesulitan dalam menyadari pengalaman akan terjadi ketidaksesuaian (incongrunce) dalam pengalaman dirinya (self experience). Ketujuh, gangguan penyesuaian diri akan muncul jika individu tidak menemukan kesenangan dan fulfillment dalam beraktivitas. Kedelapan, apabila individu hidup di lingkungan yang tidak memberikan kesempatan untuk mengembangkan dan mengeksptesikan diri (personal growth), akan berdampak pada penurunan ekspresi potensi individu (kognitif-afektif-konatif/psikomotor).

Model BK Proaktif disusun dengan mengacu kepada prinsip teori Humanistik. Kedelapan huruf dalamakronim proaktif mengandung makna dan model yang mampu memfasilitasi pengembangan diri guru BK mencapai aktualisasi potensi diri untuk menjadi sosok guru BK yang professional.

- Peka (P) dapat merupakan hasil pengalaman manusia sebagai aspek penting dalam kehi- dupannya. Rogers (1959) mengatakan bahwa kepekaan dapat dilatih dan diperoleh organisme melalui medan fenomenal dan internalisasi nilai-nilai sehingga akan membentuk konsep self. Individu yang dapat mengasah dan mengolah kepekaannya untuk tujuan yang positif dapat menjadi seorang konselor yang handal. Guru yang mampu mengasah dan mengolah kepekaannya dapat menunjang profesionalitasnya sebagai guru.

- Responsif (R), yang berarti tanggap terhadap stimulus yang diterima, juga merupakan kemampuan yang dapat diperoleh dari pengalaman sehingga dapat dipelajari. Responsif merupakan bentuk perhatian yang diberikan untuk menunjukkan empati dan kepedulian terhadap orang lain. Orang yang responsif belum tentu mengoperasionalkannya karena reflek juga dapat dipandang sebagai gerak merespon.

- Operasional atau Obah (O) adalah langkah yang harus menyertai orang yang responsif. Keterampilan ini dapat dilatih dengan cara humanis tanpa individu merasa ada ancaman yang menyertai aktivitas pelatihannya sehingga individu dapat menyesuaikan dan mengubah nilai-nilai secara terus-menerus melalui proses identifikasi dan introspeksi dari nilai-nilai orang lain agar dapat berfungsi secara penuh.

- Afektif (A) merupakan komponen pembentuk sikap manusia. Afeksi merupakan kunci untuk menjadi sosok yang mau dan mampu berempati, dapat memberikan penghargaan positif tanpa kondisi, memahami kerangka berpikir orang lain, dan menjadi fasilitator bagi pengembangan diri. Afeksi merupakan elemen penting dari emosi. Rogers mengemukakan bahwa teori humanistik menekankan emotional process bukan pada intelectual process, bukan pada apa yang dipikirkan atau dilakukan, tetapi bagaimana individu mengalami dan merasakan kehidupannya (Jarvis, 2009).

- Kognitif (K) adalah daya nalar yang sangat mengandalkan kemampuan berpikir dan juga merupakan komponen pembentuk sikap. Maslow mengemukakan bahwa teori humanistik, 
kemampuan berpikir sangat penting bagi kemauan untuk berproses dalam memenuhi kebutuhan untuk aktualisasi diri (Jarvis, 2009).

- Tingkah laku (T) manusia tidak hanya dipandang sebagai sesuatu yang mekanistik, tetapi harus dipandang sebagai kualitas manusia yang kreatif, selalu berusaha untuk dapat mengaktualisasikan dirinya, memperoleh sesuatu dan mempertahankannya. Rogers menyebut bahwa sebagian besar tingkah laku individu akan sesuai dengan pengalaman organismik yang dikonstruksikan kedalam struktur self sehingga pada umumnya tingkah laku sesuai dengan konsep self (Jarvis 2009).

- Ikhlas (I) adalah menyengajakan perbuatan semata-mata mencari keridhaan Allah dan memurnikanperbuatan dari segala bentuk kesenangan duniawi (Qardhawi, 2000). Definisi ikhlas menurut para ulama memang berbeda-beda, namun tujuannya tetap sama, yaitu mengikhlaskan berbagai aktivitas untuk mendekatkan diri hanya kepada Allah saja. Menjadi guru pada umumnya dan guru BK khususnya merupakan tugas mulia, meskipun dari sisi finansial kurang dibanggakan. Pendekatan humanistik sangat kental dengan keyakinan akan adanya kekuatan mistis yang ada secara intrinsik dalam diri setiap manusia danberkembang pesat dalam suasana yang lebih simpatik pada kebudayaan timur. Pendidikan dalam kebudayaan timur merupakan cermin dari tradisi keagamaan (Graham, 2005).

- Fasilitasi (F) merupakan peran guru ketika menjembatani keinginan peserta didik untuk memperoleh peluang bagi pengembangan diri siswa secara optimal. Pendekatan humanistik mengedepankan fasilitasi dalam dunia pendidikan dan klinis. Penekanan pendidikan secara historis juga lebih pada proses untuk mengetahui dibandingkan pada pengetahuan semata. Mengetahui dipandang sebagai proses atau perubahan yang aktif, dinamis, yang sinonim dengan proses menjadi (becoming). Pengetahuan muncul, bukan karena diberi, sifatnya mengalir dan tidak beku. Proses pendidikan dengan demikian pada dasarnya bersifat humanis dan individualis, dan menekankan pada pertumbuhan diri (selfgrowth), pengarahan diri(self-direction), dan ekspresi diri (self-expression).

Model BK Proaktif menggunakan pelatihan untuk meningkatkan keterampilan psikologis guru. Pelaksanaan secara kelompok menurut teori Adler dapat dilakukan melalui empat tahapan, yaitu; (1) membangun dan memelihara hubungan terapiutik yang tepat; (2) mengeksplorasi berbagai dinamika yang terjadi dalam diri anggota kelompok; (3) mengkomunikasikan suatu pemahaman atas diri sendiri kepada setiap anggota kelompok; (4) menemukan serta mengembangkan berbagai alternatif dan pilihan baru untuk pengembangan diri anggota kelompok. Corey (1990) mengemukakan bahwa anggota kelompok akan memperoleh pengalaman yang lebih berorientasi sosial, terintegrasi secarapribadi dan mampu memperbaiki beliefs yang salah sehingga dapat menentukan arah tujuan hidupnya. Keuntungan dari teori Adler untuk aktivitas kelompok adalah penekanan pada unsur pendidikan sehingga anggota kelompok akan menikmati pengalaman dan perasaan mereka secara realistis ketika berhubungan dengan penanganan masalah.

Cara kerja berdasarkan pada logika, akal sehat, dan menggunakan cara kognitif dan eklektik agar anggota kelompok tidak merasa terhambat oleh prosedur yang digunakan. Cara ini dapat mendorong partisipasi anggota untuk berperilaku demokratis yang berguna dalam meningkatkan keterbukaan dan dialog. Aspek perilaku dan afeksi diperhatikan serta tidak terikat dengan metode dan prosedur yang kaku.

Gambaran ringkas Keterampilan Psikologis Model BK Proaktif yang ditunjukkan pada Gambar 1. 


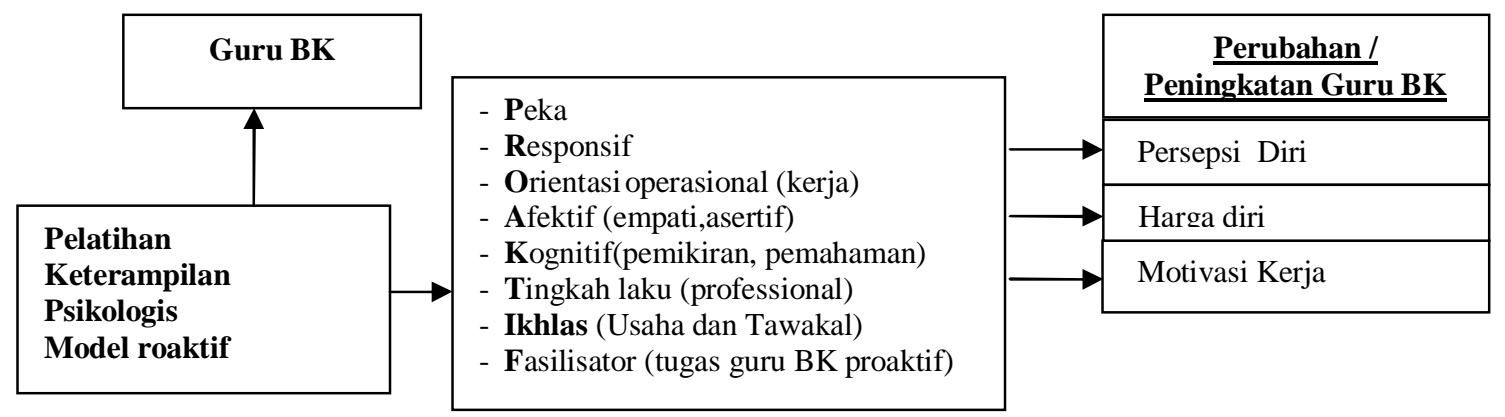

Gambar 1. Model Keterampilan Psikologis BK Proaktif

Penelitian ini mengajukan hipotesis seperti berikut. Pertama, ada perbedaan persepsi guru terhadap diri sebelum dan sesudah perlakuan. Persepsi diri guru sesudah perlakuan lebih positif dari pada sebelum perlakuan. Kedua, ada perbedaan harga diri guru antara sebelum dan sesudah perlakuan. Harga diri sesudah perlakuan lebih tinggi dari sebelum perlakuan. Ketiga, ada perbedaan motivasi kerja guru sebelum dan sesudah perlakuan. Motivasi kerja guru sesudah perlakuan lebih tinggi daripada sebelum perlakuan.

\section{METODE}

Responden dalam studi ini dibagi dalam dua kelompok, yaitu kelompok eksperimen dan kelompok kontrol yang masing-masing sejumlah delapan orang. Penentuan subjek dilakukan dengan teknik purposive sampling yang dipilih berdasarkan karakteristik tertentu, yaitu guruguru SD/MIN di Kabupaten Sleman, status sebagai guru tetap, wali kelas, telah mengajar minimal tiga tahun dan belum pernah memperoleh pelatihan keterampilan psikologis sebelumnya.
Alat pengumpulan data adalah skala pengukuran psikologis. Bentuk skala ini mengacu pada metode summated rating dengan model Likert yang dimodifikasi yang terdiri atas tujuh kategori respon. Tiap butir soal diskor yaitu: untuk pernyataan favourable nilai 1 (sangat sesuai sekali) hingga tujuh (sangat tidak sesuai sekali), non favourable nilai 7 (sangat sesuai sekali) hingga satu (sangat tidak sesuai sekali). Responden diminta untuk menilai tiap butir dan menentukan pilihan dengan menjawab pertanyaan yang sesuai dengan pernyataan dirinya. Instrumen pengukuran keterampilan psikologis terdiri atas tiga skala dengan jumlah butir yang berbeda, yaitu: (1) skala persepsi diri terdiri atas 25 butir; (2) skala harga diri 20 butir; dan (3) skala motivasi kerja 25 butir. Pengambilan data dilakukan tiga tahap, yaitu sebelum, langsung sesudah pelatihan dilaksanakan, dan setelah empat bulan kemudian.

Penelitian ini adalah quasi experiment dengan rancangan one group pretest-posttest desaign (Campbell, 1988:152) sebagaimana ditunjukkan pada Tabel 1.

Tabel 1. Rancangan Eksperimen Pre-post Test Control Group Design dengan Follow-up

\begin{tabular}{|c|c|c|c|c|}
\hline Kelompok Penelitian & $\begin{array}{l}\text { Pretes } \\
\text { (Dependent) } \\
\text { V1 V2 V3 }\end{array}$ & $\begin{array}{l}\text { Perlakuan MPKP } \\
\text { (Independent) } \\
\text { V0 }\end{array}$ & $\begin{array}{c}\text { Posttes } \\
\text { (Dependent) } \\
\text { V1 V2 V3 }\end{array}$ & $\begin{array}{l}\text { Follow-up Test } \\
\text { (Dependent) } \\
\text { V1 V2 V3 }\end{array}$ \\
\hline Kelompok Eksperimen & $\mathrm{Y0}$ & $\mathrm{X} 1$ & $\mathrm{Y} 1$ & $\mathrm{Y} 2$ \\
\hline Kelompok. Kontrol & Y0 & $\mathrm{X} 0$ & $\mathrm{Y} 1$ & $\mathrm{Y} 2$ \\
\hline \multicolumn{2}{|c|}{$\begin{array}{l}\text { Keterangan: } \\
\text { MPKP: Modul Pelatihan Keterampilan } \\
\text { (Model BK Proaktif) }\end{array}$} & Psikologis & $\begin{aligned} &: \text { Perlak } \\
& \text { pada } \\
&: \text { Kelon }\end{aligned}$ & $\begin{array}{l}\text { n dengan PKP model BK Proaktif } \\
\text { lompok eksperimen } \\
\text { ok kontrol tanpa ada perlakuan }\end{array}$ \\
\hline
\end{tabular}
lompok kontrol sebelum perlakuan dimulai 
Y1 : Post-test pada kelompok perlakuan dan kelompok kontrol sesudah perlakuan dilaksanakan

Y2 : Post-test pada kelompok perlakuan dan kelompok kontrol 2 bulan sesudah perlakuan dilaksanakan

V0 : Pelatihan keterampilan psikologis model BK Proaktif

V1 : Persepsi guru terhadap dirinya

V2 : Harga diri guru

V3 : Motivasi kerja guru

\section{Modul Pelatihan Keterampilan Psikologis Model BK Proaktif}

Pokok bahasan yang diolah dalam rancangan modul pelatihan keterampilan psikologi adalah tentang pengenalan kemampuan diri, anasis lingkungan kerja, fungsi, layanan guru dan guru BK, formulasi dan implementasi strategi, dan inovasi. Isi rancangan modul keterampilan psikologis Model BK Proaktif di SD adalah sebagai berikut.

- Memahami diri dan orang lain (siswa, orang tua dan rekan sejawat)

Tujuan: setelah mengikuti sesi ini, peserta diharapkan pelatihan dapat: (1) menyadari perlunya mengenal diri dan mengenal orang lain; (2) memahami apa arti mengenal diri dan mengenal orang lain; (3) mampu mengenali perasaan dan emosi diri serta orang lain; (4) mengenal dan memahami lingkungan kerja, budaya organisasi, budaya dan adat istiadat setempat; (5) memahami siswa (memahami perkembangan diri siswa, mengenal karakteristik siswa SD secara umum, kelebihan, kekurangan, dan hambatan dalam perkembangan serta memahami makna kedekatan hubungan); (6) memahami orang tua siswa (peran orang tua siswa dalam organisasi sekolah, harapan orang tua siswa terhadap sekolah); (7) memahami rekan sejawat, pentingnya kerjasama dan kolaborasi yang berguna bagi optimalisasi perkembangan diri pribadi, prestasi siswa, kenyamanan ditempat kerja untuk meningkatkan motivasi dan semangat kerja; dan (8) menggunakan dan menghayati Model BK Proaktif di setiap sesi
- Manajemen fungsi dan layanan BK, stres, dan pemberdayaan diri

Tujuan: setelah mengikuti sesi ini, peserta diharapkan dapat: (1) memahami lebih dalam fungsi dan layanan BK dan dampaknya bagi emosi diri dan gejala stres dalam diri; (2) membebaskan diri dari perasaan cemas yang mengganggu; (3) melakukan relaksasi sebagai cara untuk mengurangi perasaan cemas; (4) menjadi lebih berdaya, harga diri, dan kepercayaan diri meningkat; dan (5) menggunakan dan menghayati Model BK Proaktif di setiap sesi.

- Komunikasi efektif dan hubungan interpersonal yang empatik

Tujuan: setelah mengikuti sesi ini, peserta diharapkan dapat: (1) berkomunikasi asertif dan empatik secara sehat dengan siswa, orang tua siswa, rekan sejawat, dan anggota organisasi sekolah lainnya; (2) dapat mengelola konflik dalam komunikasi; (3) mengenal teknik menjadi moderator, fasilitator dan kolaborator untuk meningkatkan efektivitas, efisiensi tugas dan peran sebagai guru BK; dan (4) menggunakan dan menghayati Model BK Proaktif di setiap sesi.

- Deteksi dini siswa bermasalah.

Tujuan: Setelah mengikuti sesi ini diharapkan peserta dapat: (1) lebih peka dan mampu mengobservasi untuk melakukan deteksi dini terhadap siswa yang bermasalah; (2) memiliki strategi untuk menggali permasalahan siswa dengan efektif, aman dan nyaman; (3) latihan menyajikan topik-topik yang menarik bagi siswa di kelas untuk membekali siswa dengan life skill; (4) menggunakan dan menghayati Model BK Proaktif di setiap sesi.

- Pengembangan diri guru BK untuk siap menjadi fasilitator, moderator, dan kolaborator sehingga menjadi guru efektif dan nyaman bagi siswa

Tujuan: setelah mengikuti sesi ini, peserta dapat: (1) belajar bagaimana menjadi fasilitator dan moderator yang baik; (2) bagaimana usaha melakukan strategi negosiasi agar dapat membentuk kolaborasi yang berhasil dengan pihak terkait dengan profesi 
guru; memaknai arti harga diri, percaya diri kepuasan dan motivasi dalam kerja; (3) belajar melakukan evaluasi bagi pengembangan rancangan; dan (4) menggunakan dan menghayati Model BK Proaktif di setiap sesi.

- Pengembangan diri melalui kegiatan belajar, bermain, bekerja, dan beribadah

Tujuan: Setelah mengikuti sesi ini, peserta diharapkan dapat: (1) mengenali berbagai hambatan dalam diri untuk menuju pribadi yang sukses khususnya ketika berinteraksi dengan siswa; (2) merancang implementasi strategi bagi inovasi yang dilakukan; (3) mengetahui bahwa kegiatan belajar, bermain, bekerja dan beribadah merupakan indikator kesehatan psikologis; (4) menggunakan dan menghayati Model BK Proaktif di setiap sesi.
Metode yang digunakan: (1) ceramah; (2) permainan (disesuaikan dengan konteks budaya lokal seperti kebiasaan, lagu daerah); (3) latihan menjadi peka dan merespon, mengoperasionalkan, melatih afeksi, kognisi, bertingkahlaku, menjadi ikhlas, dan memfasilitasi; (4) diskusi; dan (5) refleksi

Analisis data menggunakan teknik statistik non-parametrik dari Mann Whitney karena jumlah subjek kurang dari 30 dan mengukur perbedaan dua kelompok subjek.

\section{HASIL DAN PEMBAHASAN}

Hasil penelitian dideskripsikan sebagai berikut. Perbedaan gain score (post-pretest) dengan (post-pretest) pada kelompok eksperimen (KE) ditunjukkan pada Tabel 2, Tabel 3, dan Tabel 4.

Tabel 2. Perbedaan Gain Score (Post1-Pretest) dengan (Post2-Pretest) pada Kelompok Eksperimen (KE)

\begin{tabular}{|c|c|c|c|}
\hline \multirow[t]{2}{*}{ Hasil Perhitungan } & \multicolumn{3}{|c|}{ Variabel } \\
\hline & Persepsi Diri (V1) & Harga Diri (V2) & Motivasi Kerja (V3) \\
\hline $\mathrm{N}$ (Jumlah subjek) & 8 & 8 & 8 \\
\hline Mann Whitney U (z) & 0,023 & 0,60 & 0,002 \\
\hline $\begin{array}{l}\text { Mean (rerata) Gain Score } \\
\text { (Post1-Pretest) }\end{array}$ & 19,7778 & 7,2222 & 31,0000 \\
\hline Standard Deviation (SD) & 21,01735 & 10,38963 & 11,61895 \\
\hline $\begin{array}{l}\text { Mean (rerata) Gain Score } \\
\text { (Post2-Pretest) }\end{array}$ & $-1,6667$ & $-7,5556$ & 4,2222 \\
\hline Standard Deviation (SD) & 16,73320 & 20,01157 & 11,69164 \\
\hline
\end{tabular}

Tabel 3. Hasil uji perbedaan Gain Score (Post2-Pretest) dengan Gain Score (Post2- Post1) pada Kelompok Eksperimen (KE)

\begin{tabular}{lccc}
\hline Hasil Perhitungan & Persepsi Diri (V1) & $\begin{array}{c}\text { Variabel } \\
\text { Harga Diri (V2) }\end{array}$ & Motivasi Kerja (V3) \\
\hline N (Jumlah subjek) & 8 & 8 & 8 \\
\hline Mann Whitney U (z) & 0,027 & 0,091 & 0,001 \\
Mean (rerata) Gain Score & $-1,6667$ & $-7,5556$ & 4,2222 \\
(Post2-Pretest) & & & \\
Standard Deviation (SD) & 16,73320 & 20,01157 & 11,69164 \\
Mean (rerata) Gain Score & $-21,1111$ & $-14,8889$ & $-26,5556$ \\
Post2 Post1) & & & \\
Standard Deviation (SD) & 24,11661 & 13,97716 & 14,69788 \\
\hline
\end{tabular}


Tabel 4. Hasil Uji Perbedaan Gain Score (Post2-Pretest) antara Kelompok Eksperimen (KE) terhadap Kelompok Kontrol (KK)

\begin{tabular}{|c|c|c|c|c|c|c|}
\hline \multirow{4}{*}{$\begin{array}{l}\text { Hasil Perhitungan } \\
\text { N (Jumlah subjek) }\end{array}$} & \multicolumn{6}{|c|}{ Variabel } \\
\hline & \multicolumn{2}{|c|}{ Persepsi Diri (V1) } & \multicolumn{2}{|c|}{ Harga Diri (V2) } & \multicolumn{2}{|c|}{ Motivasi Kerja (V3) } \\
\hline & KE & KK & KE & KK & $\mathrm{KE}$ & KK \\
\hline & 8 & 8 & 8 & 8 & 8 & 8 \\
\hline \multirow{2}{*}{$\begin{array}{l}\text { Mann Whitney U (z) } \\
\text { Mean (rerata) Gain Score } \\
\text { (Post } 2 \text {-Pretest) }\end{array}$} & \multicolumn{2}{|c|}{0,630} & \multicolumn{2}{|c|}{0,111} & \multicolumn{2}{|c|}{0,360} \\
\hline & $-1,6667$ & 0,2500 & $-7,5556$ & 0,2500 & 4,2222 & $-8,750$ \\
\hline Standard Deviation (SD & 16,73320 & 13,83319 & 20,01157 & 11,25992 & 11,69164 & 22,04176 \\
\hline
\end{tabular}

Berdasarkan hasil uji U (z) untuk variabel persepsi diri diperoleh $\mathrm{z}=0,023, \mathrm{p}<0,05$ yang berarti ada perbedaan persepsi diri yang signifikan antara post 1-pretest dengan post 2pretest. Pada variabel harga diri, diperoleh $\mathrm{z}=$ 0,$60 ; p>0,05$ yang berarti bahwa tidak ada perbedaan signifikan mengenai harga diri antara post-pretest dengan post2-pretest. Pada variabel motivasi kerja diperoleh $\mathrm{z}=0,002 ; \mathrm{p}<0,05$, yang berarti bahwa ada perbedaan signifikan motivasi kerja antara post 1-pretest dengan post 2pretest.

Berdasarkan hasil uji U (z) untuk variabel persepsi diri diperoleh $\mathrm{z}=0,027 ; \mathrm{p}<0,05$ yang berarti ada perbedaan persepsi diri yang signifikan antara post2-pretest dengan post2post1. Pada variabel harga diri, diperoleh $\mathrm{z}=$ 0,091; $p>0,05$ yang berarti bahwa tidak ada perbedaan signifikan mengenai harga diri antara post2-pretest dengan post 2 -post 1 . Untuk variabel motivasi kerja diperoleh $\mathrm{z}=0,001 ; \mathrm{p}<0,05$, yang berarti bahwa ada perbedaan signifikan motivasi kerja antara post2-pretest dengan post2post 1 .

Berdasarkan hasil uji U (z) untuk variabel persepsi diri diperoleh $\mathrm{z}=0,630 ; \mathrm{p}>0,05$ yang berarti tidak ada perbedaan persepsi diri yang signifikan pada post 2 -pretest antara KE terhadap KK. Pada variabel harga diri, diperoleh $\mathrm{z}=0,111 ; \mathrm{p}>0,05$ yang berarti bahwa tidak ada perbedaan signifikan mengenai harga diri antara post2-pretest. Pada variabel motivasi kerja diperoleh $\mathrm{z}=0,360 ; \mathrm{p}>0,05$, yang berarti bahwa tidak ada perbedaan signifikan motivasi kerja post2-pretest antara KE terhadap KK.

\section{Pembahasan}

Pelatihan keterampilan psikologis Model BK Proaktif merupakan perpaduan pelatihan antara teori dengan praktek. Model pelatihannya yaitu (PRO) peduli, respon, dan operasional menjadi hasil akhir keterampilan yang ditampakkan (AKT) afektif, kognitif, dan tingkah-laku sebagai landasan teori, (IF) ikhlas dan fasilitator menjadi landasan pokok penunjang pelaksanaan keterampilan psikologis.

Pada hari pertama peserta pelatihan melakukan perubahan paradigma dalam mempersepsi diri, harga diri, dan motivasi kerja sebagai pendidik. Peserta diminta untuk mengenal akan kelebihannya, mengetahui cita-cita hidupnya, mengenal makna profesinya, mengenal profil guru yang telah sukses dalam mendidik anak, mengenal potensi sekolah dan potensi siswa. Membuat surat motivasi antarguru dan membacakannya sebagai penyemangat dalam mendidik dengan keterampilan psikologis BK Proaktif, latihan merubah fisiologis mengajar (nada suara, senyuman, sentuhan, mengemukakan kalimat positif).

Hari kedua peserta pelatihan menerapkan keterampilan BK Proaktif. Peserta berlatih memberikan pujian, membuat kalimat positif untuk siswa, membuat kalimat afirmasi untuk sekolah, latihan resensi effect mengenalkan cita-cita kepada siswa, belajar bercerita, dan berlatih olah tubuh dan olah rasa. Peserta dilatih bersikap 
verbal dan nonverbal dalam berbicara, memberikan motivasi kepada siswa yang dilakukan berulang selama proses pelatihan. Melakukan latihan yang berulang-ulang akan meningkatkan keterampilan peserta. Semakin sering mengadakan pelatihan, semakin terampil dalam menerapkan BK Proaktif.

Hasil penelitian menunjukkan bahwa pada kelompok eksperimen, kontribusi pelatihan terhadap perubahan persepsi diri dan motivasi kerja signifikan, kecuali harga diri tidak signifikan meskipun dari nilai rerata menunjukkan ada peningkatan. Pada post test 1 , peningkatan cukup tinggi, namun menurun cukup tinggi pula pada post test 2 setelah selang empat bulan setelah pelatihan. Keadaan ini menunjukkan bahwa pelatihan belum dapat teruji untuk mempertahankan perubahan dalam waktu yang lebih lama. Banyak hal yang berpengaruh, baik faktor internal maupun eksternal, misalnya kondisi pribadi peserta (tingkat kemampuan umum, daya ingat, motivasi intrinsik), lama pelatihan, media pembelajaran, kebijakan pemerintah, dan pengaruh luar lainnya.

Data observasi dan wawancara yang dilakukan setelah pelatihan menunjukkan bahwa responden merasa sangat senang dengan program pelatihan dan berharap akan dapat dilaksanakan secara berkala. Alasannya, supaya selalu ingat, tidak mudah lupa, dan dapat mengurangi stres kerja. Peningkatan cukup tinggi terjadi pada variabel persepsi diri dan motivasi kerja. Searah dengan teori humanistik dari Rogers, yaitu bahwa pelatihan Model BK Proaktif telah memberikan kesempatan kepada subjek untuk mengembangkan potensi diri sehingga terbuka kesempatan untuk aktualisasi diri jika persepsi diri meningkat menjadi lebih baik (Cremers, 1987). Unsur konsep diri, komitmen, dan motivasi adalah hal penting yang diperlukan dalam setiap pencapaian tujuan kegiatan. Hal itu terlihat dalam hasil penelitian Mulyono (2013) yang menunjukkan adanya hubungan yang signifikan antara konsep diri, komitmen, dan motivasi berprestasi dalam olah raga.

Uji perbedaan gain score pre test dan postst 2 pada kelompok kontrol tidak menunjukan perbedaan yang signifikan. Hal ini diduga karena responden penelitian meskipun secara statistik dinyatakan homogen namun dari hasil observasi dan wawancara peneliti menemukan responden pada kelompok kontrol mempunyai kemampuan komunikasi yang berbeda dengan kelompok eksperimen. Dua responden pernah mengikuti pelatihan guru, lokasi sekolah di daerah perkotaan dibanding kelompok eksperimen yang terletak di lingkungan desa. Dari segi pendidikan responden kelompok kontrol lebih banyak lulusan sekolah tinggi ilmu pendidikan dibandingkan dari kelompok eksperimen. Hal-hal inilah yang diduga meskipun pelatihan memiliki kontribusi meningkatkan keterampilan psikologis, persepsi diri, harga diri, dan motivasi kerja kelompok eksperimen namun tidak memiliki perbedaan dengan kelompok kontrol karena skor pada kelompok kontrol sudah tinggi.

\section{PENUTUP}

Sesuai dengan hipotesis yang dikemukakan sebelumnya, hasil penelitian memperlihatkan hal-hal sebagai berikut. Pertama, ada perbedaan persepsi guru terhadap diri sebelum dan sesudah perlakuan. Persepsi diri guru sesudah perlakuan lebih positif dari pada sebelum perlakuan. Kedua, ada perbedaan harga diri guru antara sebelum dan sesudah perlakuan. Harga diri sesudah perlakuan lebih tinggi dari sebelum perlakuan. Ketiga, tidak ada perbedaan motivasi kerja guru sebelum dan sesudah perlakuan. Motivasi kerja guru sesudah perlakuan lebih tinggi daripada sebelum perlakuan.

\section{UCAPAN TERIMA KASIH}

Penelitian ini tidak akan sampai pada kesimpulan akhir tanpa bantuan dari banyak pihak. Oleh karena itu, pada kesempatan ini peneliti ingin menyampaikan rasa terima kasih yang tak terhingga kepada: (1) Fakultas Psikologi UGM yang telah mendanai penelitian ini melalui Program Hibah Fakultas Psikologi; (2) Guruguru Sekolah Dasar/MIN Tempel di Kabupaten Sleman yang telah bersedia sebagai peserta pelatihan; (3) Fatan, S.Psi., Denis, S.Psi., dan Farida Aryati, S.Psi. yang mendampingi peneliti selama proses penelitian berlangsung dan Adelia Khrisna Putri, S.Psi. yang banyak berperan 
dalam proses penyempurnaan naskah hasil penelitian ini; (4) Jurnal Pendidikan Cakrawala, Universitas Negeri Yogyakarta, khususnya Bapak Burhan Nurgiyantoro selaku Ketua Redaktur dan Sdr. Binar yang telah bersedia memuat naskah hasil penelitian ini sehingga sampai ke tangan sidang pembaca. Semoga membawa manfaat bagi banyak kalangan.

\section{DAFTAR PUSTAKA}

Adler, A. 1956. The Individual Psychology of Alfred Adler. New York: Basic Books.

Aldrige, J., \& Clayton, G. 1990. "Source of Self-Esteem: Perception of Education Majors". Psychological Abstract. Vol.8 pages 27-29.

Alwisol, 2007. Psikologi Kepribadian. Edisi Revisi. Malang: UMM Press.

Campbell, D T, \& Julian C.S. 1988. Eksperimental and Quasi Experimental Designs for Research. Chicago: Rand McNally.

Corey, G. 1990. Theory and Practice of Group Counseling. Pacific Grove, CA: Brooks/ Cole Publishing Company.

Covey, S.R. 1989. The Seven Habits of Highly Effective People. New York: A Fireside Book.

Cremers, A. 1987. Antara Engkau dan Aku. Jakarta: PT. Gramedia.

Dirjen Dikdasmen. 2002. "Kebijakan Direktorat Jenderal Pendidikan Dasar dan Menengah dalamPembinaan dan Pengembangan Tenaga Kependidikan Khususnya Guru Pembimbing". Makalah Seminar dan Lokakarya Nasional Standardisasi Profesi Bimbingan dan Konseling. Yogyakarta: 24-25 Oktober.

Glasheen, A. Campbell, M.A. Shochet. I. 2013. "Opportunities and Challenges; School Guidance Counsellor's Perceptions of
Counselling Students Online". Australian Journal of Guidance and Counselling, page 1 of 14 .

Graham, H. 2005. Psikologi Humanistik dalam Konteks Sosial, Budaya, dan Sejarah. (Terjemahan). Yogyakarta: Pustaka Pelajar.

Hadjam, M.N.R. 2005. "Keterampilan Psikologis dalam Mewujudkan Kesehatan Mental". Naskah pidato pada Pengukuhan Jabatan Guru Besar pada Fakultas Psikologi Universitas Gadjah Mada. Yogyakarta

Huntington, S.P. 2001. Benturan Antar Peradaban dan Masa Depan Politik Dunia. Yogyakarta: Qalam.

Jarvis, M. 2009. Teori-teori Psikologi. Pendekatan Modern untuk Memahami Perilaku, Perasaan \& Pikiran Manusia. (Terj. Cetakan ke III). Bandung: Penerbit Nusa Media.

Joyce, B., \& Weil, M. 1980. Models of Teaching. London: Prentice-Hall International, Inc.

Mulyono, Boyke. 2013. "Hubungan Konsep Diri, Komitmen, dan Motivasi Berprestasi dengan Prestasi Renang Gaya Bebas". Cakrawala Pendidikan, Vol XXXII, No. 3, hlm. 488-498.

Nurihsan, A. Juntika \& Sudianto Akur. 2005. Manajemen Bimbingan \& Konseling di SMP Kurikulum 2004. Jakarta: PT. Gramedia Widiasarana Indonesia.

Qardhawi, Y. 2000. Ikhlas Sumber Kekuatan Islam. Yogyakarta: Gema Insani Press.

Rae, L. 2005. Using People Skills in Training and Development. Jakarta: PT. Gramedia.

Sanmustari, B.R. 1988. "Nilai Kerja pada Kelompok-kelompok Karyawan”. Tesis. Jakarta: Universitas Indonesia (Tidak Diterbitan). 
Schemerhorn, John R., Hunt, James G., Osborn Richard N. 2002. Organizational Behavior, $7^{\text {th }}$ Edition. Phoenix: John Wiley \& Sons.

Silberman, M. 1998. Active Training. USA: Jossey-Bass

Temple, S., \& Robson, P. 1991. "The Effect of Assertive on Self-Esteem". Occupational Therapy. Vol. 54 p.329-332.
Torunoglu. H., Genctanirim. D. 2015. The Perceptions of School Counsellors about the Counseling and Guidance Programs of Vocational High Schools. Procedia-Social and Behavioral Sciences. 174. Pages 368-376.

UNICEF. 2000. Skills-Based Health Education to Prevent HIV/AIDS. www.unicef.org.

Walgito, B. 2002. Pengantar Psikologi Umum. Yogyakarta: Andi offset. 